\title{
KEPUASAAN IBU PADA PELAYANAN KESEHATAN IBU DAN ANAK DI UPTD PUSKESMAS JAPAH KABUPATEN BLORA
}

\author{
Sri Purwati ${ }^{1)}$; Sri Rahayu ${ }^{2)}$; Kuswanto ${ }^{3)}$ \\ yayoeksr74@yahoo.com,spwblora@gmail.com.
}

\begin{abstract}
ABSTRAK
Patient dissatisfaction synonymous with complaints against the service. Patient satisfaction depends on the quality of service (Supranto J, 2006). Whether or not the service can be seen from how big the dimension of service quality through five principles of Service Qualit), like: Tangible (physical evidence), Reliability (reliability), responsiveness (Responsiveness), Assurance (Assurance), Empathy (Empathy) (Hardiyansyah, 2011). The purpose of this study was to determine faktot-factors associated with maternal satisfaction of visitors poly KIA.This research was conducted in a poly KIA UPTD Japah PHC in March to May 2016 This research is a correlation with cross sectional approach, using the method of survey research subjects mother visitors poly KIA and PONED with the samples according to the criteria of 100 respondents with accidental sampling method. The data were analyzed using univariate and bivariate Continuity Correction.The results showed a good percentage of satisfaction dimensional aspect more than the percentage that is not good. The results of the percentage satisfied to the satisfaction aspect as much as $66 \%$, both aspects of physical evidence as much as $72 \%$, good reliability aspects as much as $77 \%$, the responsiveness of both aspects as much as $62 \%$, better guarantee as much as $64 \%$, and a good empathy as much as $66 \%$. Continuity Correction of test results on five dimensions of quality that physical evidence, responsiveness, kehandalaan, assurance and empathy showed that no significant relationship with patient satisfaction.
\end{abstract}

Keywords: Kepuaasn patients KIA, 5 Dimensions namely Physical Evidence Quality, Reliability, power responsiveness, assurance and empathy

1), 2), 3) Civitas Akademika Poltekkes Kemenkes Semarang

Millennium Development Goals (MDGs) sebagai arah pembangunan kesehatan di Indonesia mempunyai delapan tujuan, dimana dua diantaranya adalah untuk menurunkan Angka Kematian Ibu (AKI) dan Angka Kematian Bayi (AKB). Pencapaian tujuan milenium yaitu AKI ditekan menjadi 102 per 100.000 kelahiran hidup terancam gagal dengan meningkatnya AKI. Survei Demografi dan Kesehatan Indonesia tahun 2012 AKI sebesar 359 per 100.000 kelahiran hidup. Menurut Ali Ghufron, tingginya AKI terutama akibat keterlambatan penanganan kehamilan, sehingga pemerintah saat ini memfokuskan upaya perbaikan layanan primer sebagai ujung tombak pelayanan kesehatan (Badan Litbangkes Kemenkes RI, 2013).

AKI Provinsi Jawa Tengah tahun 2014 berdasarkan laporan dari kabu- 
paten/kota sebesar 126,55/100.000 kelahiran hidup, mengalami peningkatan bila dibandingkan dengan AKI pada tahun 2013 sebesar 118,62 / 100.000 kelahiran hidup, hal ini berarti terjadi peningkatan permasalahan kematian ibu di Provinsi Jawa Tengah. Sedangkan AKB di Provinsi Jawa Tengah tahun 2014 sebesar 10,08/1.000 kelahiran hidup, terjadi sedikit penurunan bila dibandingkan dengan tahun 2013 sebesar 10,41/1.000 kelahiran hidup (Dinkes Prop, 2014).

Kabupaten Blora AKI tahun 2013 119,00 per $100.000 / \mathrm{KH}$ (14 kematian), tahun 2014 turun menjadi 99,04 per $100.000 / \mathrm{KH}$ (12 kematian) dan tahun 2015 naik menjadi 124/100.00 KH (15 kematian). Sedangkan AKB pada tahun 2014 16,84/1000 KH, tahun 2015 14,07/1000 KH (DKK Blora, 2015).

AKI mencerminkan risiko yang dihadapi ibu-ibu selama kehamilan dan melahirkan yang dipengaruhi oleh status gizi ibu, keadaan sosial ekonomi, keadaan kesehatan yang kurang baik menjelang kehamilan, kejadian berbagai komplikasi pada kehamilan dan kelahiran, tersedianya dan penggunaan fasilitas pelayanan kesehatan ternasuk pelayanan prenatal dan obstetri. Tingginya angka kematian ibu menunjukkan keadaan sosial ekonomi yang rendah dan fasilitas pelayanan kesehatan termasuk pelayanan prenatal dan obstetri yang rendah pula. Kematian ibu biasanya terjadi karena tidak mempunyai akses ke pelayanan kesehatan ibu yang berkualitas, terutama pelayanan kegawatdaruratan tepat waktu yang dilatarbelakangi oleh terlambat mengenal tanda bahaya dan mengambil keputusan, terlambat mencapai fasilitas kesehatan, serta terlambat mendapatkan pelayanan di fasilitas kesehatan (Kemenkes RI, 2013).

Salah satu upaya yang telah dilaksanakan untuk mempercepat penurunan AKI dan AKB melalui Upaya kesehatan tingkat pertama di Puskesmas yang dilaksanakan dalam bentuk rawat jalan melalui pelayanan Kesehatan Ibu dan Anak, rawat inap termasuk pelayanan persalinan normal 24 jam dan pelayanan gawat darurat melalui Pelayanan Obstetri Neonatal Emergensi Dasar (PONED) (Kemenkes RI, 2013).

UPTD Puskesmas Japah merupakan Puskesmas rawat jalan yang berdiri sejak tahun 1984 dan merupakan Puskesmas rawat inap mulai pada tahun 2008. Kemudian pada tahun 2011 memperluas jangkauan pelayanan menjadi Puskesmas mampu PONED. Sosialisasi tentang keberadaan dan fasilitas yang dimiliki oleh UPTD Puskesmas Japah telah dilakukan pada setiap kali dilaksanankan rapat lintas sektoral (UPTD Puskesmas Japah, 2015).

Berdasarkan data dari UPTD Puskesmas Japah kunjungan rawat jalan KIA dan PONED UPTD di setiap tahunnya mengalami penurunan. Pada tahun 2013 kunjungan poli KIA sebanyak 2.016 yang terdiri dari kunjungan ibu hamil, ibu nifas dan KB sebanyak 1.123, kunjangan bayi dan balita baik sehat maupun sakit sebanyak 893. Tahun 2014 kunjungan sebanyak 1.440 yang terdiri dari kunjungan ibu hamil, ibu nifas, dan KB sebanyak 640, kunjungan bayi dan balita sehat dan sakit sebanyak 800 . Pada tahun 2015 kunjungan poli KIA sebanyak 1.152 yang terdiri dari kunjungan ibu hamil, ibu nifas dan KB 
sebanyak 632 dan kunjungan bayi dan balita sehat sakit sebanyak 520 .

Dari 10 Puskesmas mampu PONED di wilayah Kabupaten Blora, PONED UPTD Puskesmas Japah mencapai cakupan yang paling rendah. Pada tahun 2013 sebanyak 338 ibu bersalin dan yang bersalin di PONED adalah sebanyak $56 \mathrm{ibu}$ bersalin, pada tahun 2014 sebanyak 423 ibu bersalin sedangkan yang bersalin di PONED adalah sebanyak 43 ibu bersalin. Dimana pada setiap tahunnya mengalami penurunan (UPTD Puskesmas Japah, 2015).

Penurunan jumlah kunjungan di Poli rawat jalan KIA dan kunjungan PONED, ditambah lagi dengan diterimanya komplain dari masyarakat serta terdapat kesenjangan cakupan antara K1, K4, Pertolongan Nakes, KF, KN Lengkap, KB dan deteksi resiko tinggi dari analisa data PWS, maka dari itu pelayanan yang diberikan harus lebih ditingkatkan lagi (UPTD Puskesmas Japah, 2015).

Dari study pendahuluan yang dilakukan terhadap $10 \mathrm{Ibu}$-ibu pengunjung poli KIA dan PONED mendapatkan hasil bahwa 6 orang dari ibu-ibu pengunjung Poli KIA dan PONED mengeluhkan pelayanan yang diberikan oleh bidan sangat lamban dan kurang komunikasi, 2 orang mengeluhkan bidan selaku pemberi pelayanan kurang perhatian dengan pasien yang mereka hadapi, dan 2 orang mengatakan cukup puas dengan pelayanan di Poli KIA dan PONED.

Baik atau tidaknya pelayanan dapat dilihat dari seberapa besar dimensi kualitas pelayanan melalui 5 prinsip Service Qualit), seperti: Tangible (bukti fisik), Reliability (keandalan), Responsiveness (Daya Tang- gap), Assurance (Jaminan), Emphaty (Empati) (Hardiyansyah, 2011).

Dari latar belakang di atas dapat dirumuskan permasalahan sebagai berikut "Faktor faktor apa saja yang berhubungan dengan kepuasan pasien KIA di UPTD Puskesmas Japah tahun 2016 ?

\section{Metode}

Jenis penelitan adalah kuantitatif pendekatan cross sectional yaitu suatu penelitian dimana data yang menyangkut variable bebas atau resiko dan variable terikat atau variable terikat, akan dikumpulkan dalam waktu bersamaan.

Populasi penelitian ini adalah ibuibu yang berkunjung di poli KIA dan PONED UPTD Puskesmas Japah pada bulan Maret 2016 sampai bulan Mei 2016. Dengan rata-rata kunjungan ibu hamil, ibu nifas dan KB sebanyak 60 perbulan dan kunjungan balita sehat maupun sakit sebanyak 50 perbulan. Sedangkan rata-rata kunjungan ibu bersalin sebanyak 5 orang perbulan.

Jumlah sampel 100 ibu yang berkunjung di Poli KIA pada bulan Maret sampai Mei 2016. Teknik sampling yang digunakan accidental sampling.

Jenis data yang akan digunakan dalam penelitian ini adalah meliputi : data bukti fisik, kehandalan, daya tanggap, jaminan, empati dan kepuasaan ibu pengunjung Poli KIA dan PONED.

Analisa Univariat dilakukan terhadap tiap variable dari hasil penelitian yang menghasilkan distribusi dan frekuensi dari setiap variabel yaitu Kepuasan, bukti fisik, kehandalan, daya tanggap, jaminan dan empati. Analisis Bivariat menggunakan tabel 
kontingensi $2 \times 2$ dengan $\mathrm{N}>40$, maka uji yang digunakan adalah uji $X$

\begin{tabular}{|c|c|c|}
\hline Variabel & $\begin{array}{c}\text { Frekuens } \\
\text { i (f) }\end{array}$ & $\begin{array}{c}\text { Persentas } \\
\text { e }(\%)\end{array}$ \\
\hline \multicolumn{3}{|l|}{ Kepuasaan } \\
\hline - Tidak Puas & 34 & 34 \\
\hline Puas & 66 & 66 \\
\hline Total & 100 & 100 \\
\hline \multicolumn{3}{|l|}{ Bukti Fisik } \\
\hline - Tidak Baik & 28 & 28 \\
\hline Baik & 72 & 72 \\
\hline Total & 100 & 100 \\
\hline \multicolumn{3}{|l|}{ Kehandalan } \\
\hline - Tidak Baik & 23 & 23 \\
\hline Baik & 77 & 77 \\
\hline Total & 100 & 100 \\
\hline \multicolumn{3}{|l|}{ Daya Tanggap } \\
\hline - Tidak Baik & 38 & 38 \\
\hline Baik & 62 & 62 \\
\hline Total & 100 & 100 \\
\hline \multicolumn{3}{|l|}{ Jaminan } \\
\hline - Tidak Baik & 36 & 36 \\
\hline Baik & 64 & 64 \\
\hline Total & 100 & 100 \\
\hline \multicolumn{3}{|l|}{ Empati } \\
\hline - Tidak Baik & 34 & 34 \\
\hline Baik & 66 & 66 \\
\hline Total & 100 & 100 \\
\hline
\end{tabular}

statistik Chi square Ho ditolak, apabila $p$ value $\leq 0.05$ yang artinya signifikan atau ada hubungan antara 5 dimensi mutu pelayanan dengan kepuasaan ibu pengunjung Poli KIA dan PONED.

\section{HASIL DAN PEMBAHASAN}

Analisis univariat dilakukan terhadap tiap variabel-variabel penelitian. Pada analisis ini menghasilkan distribusi frekuensi dan persentase dari variabel variabel faktor faktor yang mempengaruhi kepuasan pelayanan KIA di Puskesmas Japah.

Tabel 4.1.Distribusi Responden berdasarkan Kepuasan dan 5 Dimensi Mutu
Analisa dari hasil penelitian bahwa pengunjung di poli KIA UPTD Puskesmas Japah ada 34\% mengalami ketidakpuasan karena pelayanan yang diterimanya. Pelayanan yang mereka dapatkan tidak sesuai dengan harapan, mereka berharap pelayanan yang cepat tanggap, ramah, dan transparan dalam segala hal. Kepuasan pelanggan menurut Kirom B, 2015 adalah "customer satisfaction is customers perception that a supplier has met or exceeded ehir expectation." Dari definisi tersebut dapat ditelaah bahwa kepuasaan pelanggan dalam hal ini adalah persepsi masyarakat akan kenyataan dari realitas yang ada yang dibandingkan dengan harapan-harapan yang ada. Atau adanya perbedaan antara harapan konsumen terhadap suatu pelayanan yang diberikan oleh penyedia layanan.

Faktor yang menyebabkan ketidakpuasaan dari 34\% responden dengan pelayanan di Poli KIA UPTD Puskesmas Japah, terutama dari segi pemberi layanan yang beraneka karakter. Dimana di setiap hari terdapat pergantian petugas layanan. Sebanyak $24 \%$ responden tidak puas dan kecewa cara bidan menanggapi keluhan dari responden..

Analisis jawaban responden menunjukkan bahwa masih banyak aspek dari dimensi mutu pelayanan yang menyebabkan ketidakpuasaan dari responden. Terutama aspek dari bukti fisik tentang kenyamanan tempat periksa. Dari aspek empati dan aspek jaminan dalam pelayanan juga masih menyebabkan ketidak puasaan dari responden.Dari berbagai aspek tersebut saling berkaitan yang dapat menyebabkan bertumpuknya permasalahan yang menyebabkan ketidak puasaan. 
Hal tersebut diperkuat oleh penelitian dari Hernanta Fardhani, 2010, bahwa faktor mutu layanan dan prosedur pelayanan signifikan terhadap kepuasaan masyarakat.

Menurut Purwoastuti, dkk, 2015, tingkat kepuasan adalah suatu fungsi dari perbedaan anatara penampilan yang dirasakan dan harapan Ada 3 tingkat kepuasan, bila penampilan kurang dari harapan pelanggan tidak dipuaskan, bila penampilan sebanding dengan harapan, pelanggan puas, apabila penampilan melebihi harapan, pelanggan amat puas atua senang.

Hasil penelitian sebanyak 28\% responden mempersepsikan bukti fisik yang tidak baik, disebabkan oleh beberapa faktor yaitu ada 55\% responden yang mempersepsikan bahwa setelah dipakai alat-alat tidak ditata dengan rapi kembali dan alat-alat tersebut berserakan di meja tempat periksa. Kerapian yang kurang menyebabkan tempat periksa menjadi tidak nyaman dan terkesan amburadul. Mengenai kelengkapan bidan dalam penggunaan alat, ada $50 \%$ responden yang mempersepsikan bahwa bidan tidak memakai peralatan dengan lengkap pada waktu memeriksa pasien. Dalam penegakan diagnosa harus dilakukan pemeriksaan dengan lengkap memakai alat-alat yang sessuai standar. Jika pemeriksaan tidak memakai alatalat dengan baik diagnosa yang ditegakkan kurang bisa dipertanggungjawabkan. Responden juga mempersepsikan bahwa proses pendaftaran sulit dan rumit yaitu sebanyak $20 \%$, pada dasarnya pendaftaran tidak rumit dan sulit, namun pada proses pendaftaran memang harus sesuai dengan prosedur.
Menurut Purwoastuti, dkk, 2015, bukti fisik merupakan ketertarikan akan kualitas fisik, perlengkapan, dan material yang digunakan perusahaan, serta penampilan karyawan. Bukti fisik sangat berpengaruh dari tenaga pemberi layanan. Pemberi layanan disetiap hari berganti tenaga. Sehingga banyak karakter yang berbeda yang ditemui oleh responden.

Hal tersebut sesuai dengan Hardiyansyah, 2011, Untuk Dimensi Tangibel (Berwujud), terdiri atas indikator: penampilan Petugas / aparatur dalam melayani pelanggan, kenyamanan tempat melakukan pelayananan, kemudahan dalam proses pelayanan, kedisplinan petugas/aparatur dalam melakukan pelayanan, kemudahan akses pelanggan dalam permohonan pelayanan.

Ketidaknyaman yang disebabkan karena faktor tempat layanan memang sangat mempengaruhi responden. Responden tidak bisa merasa nyaman pada saat dilakukan pemeriksaan. Sedangkan kesulitan dalam mendapatkan akses pelayanan disebabkan karena keterbatan petugas dalam memberikan pelayanan yang cepat. Sedangkan para pemberi layanan yang tidak memakai peralatan dalam memeriksa hal ini perlu mendapatkan perhatian khusus.

Ketidak puasaan karena layanan fisik juga diperkuat oleh penelitian yang dilakukan Wike Diyah Anjaryani, 2009. Dari penelitian tersebut diketahui bahwa faktor karakteristik pemberi layanan berpengaruh signifikan terhadap kepuasaan pasien rawat inap di RSU Tugu Semarang.

Tabel 4.13.

Hubungan Bukti Fisik dengan Kepuasaan Ibu pada pelayanan KIA. 


\begin{tabular}{|c|c|c|c|c|c|c|}
\hline \multirow{3}{*}{$\begin{array}{l}\text { Bukti } \\
\text { Fisik }\end{array}$} & \multicolumn{4}{|c|}{ Kepuasan } & \multirow{2}{*}{\multicolumn{2}{|c|}{ Total }} \\
\hline & \multicolumn{2}{|c|}{ Tidak Puas } & \multicolumn{2}{|c|}{ Puas } & & \\
\hline & $\mathrm{n}$ & $\%$ & $\mathrm{n}$ & $\%$ & $\mathrm{n}$ & $\%$ \\
\hline Tidak & 15 & 53,8 & 13 & 46,4 & 28 & 100 \\
\hline Baik & & & & & & \\
\hline Baik & 19 & 26,4 & 53 & 72,6 & 72 & 100 \\
\hline Jumla & 34 & 34 & 66 & 66 & 10 & 100 \\
\hline h & & & & & 0 & \\
\hline
\end{tabular}

Analisa hasil penelitian dari hubungan aspek bukti fisik dengan kepuasaan menunjukkan bahwa aspek fisik yang baik mempunyai prosentase kepuasan yang lebih banyak yaitu $72,6 \%$ dibandingkan persepsi responden tentang bukti fisik yang tidak baik yaitu $46,4 \%$.

Bukti fisik merupakan cerminan dari luar mengenai layanan yang akan diberikan oleh Puskesmas Japah. Dari analisa diatas menunjukkan bahwa bukti fisik memang sangat berpengaruh terhadap kepuasaan pelanggan. Dengan bukti fisik yang baik dapat memperoleh prosentase kepuasaan yang lebih banyak dibandingkan dengan aspek bukti fisik yang tidak baik.

Hasil uji Correction Continuity dengan tingkat kesalahan $(\alpha) 5 \%$, didapatkan hasil nilai signifikan atau probabilitas 0.019 maka Ho ditolak dan Ha diterima, sehingga dapat disimpulkan bahwa ada hubungan antara Bukti Fisik dengan Kepuasaan Ibu pada pelayanan KIA.

Bukti fisik yang baik akan membuat pasien menjadi nyaman dalam menjalani proses anamnese dan pemeriksaan. Dalam beberapa hal seperti penampilan petugas dapat memberikan kesan pertama yang menarik bagi pasien pengunjung poli KIA UPTD Puskesmas Japah.

Hal tersebut juga sesuai dengan penelitian oleh Harentama Fardhani
2010. Bahwa mutu layanan tentang bukti fisik terbukti memberikan pengaruh terhadap kepuasaan pengunjung di Pelayanan Badan Pelayanan Perijinan Terpadu Kota Semarang.

Ketidakpuasan menunjukkan bahwa harapan dari indikator aspek kehandalan ada beberapa indikator yang belum terpenuhi. Indikator tersebut terutama adalah kecermatan petugas dalam melayani pelanggan. Bidan masih kurang teliti dalam memeriksa pasien. Bidan memeriksa pasien tidak urut mulai dari rambut sampai dengan kaki..

Dari pengamatan peneliti ditempat penelitian menunjukkan bahwa ketersediaaan SOP pelayanan memang belum memenuhi standar permenkes. Pada dasarnya dengan disediakannya SOP pada setiap ruangan pemeriksaan akan mengingatkan pemberi layanan setiap langkah dalam tindakan asuhan kebidanan.

Menurut Alimul aziz, 2008. Ilmu pengetahuan dan teknologi juga sangat mempengaruhi pelayanan kesehatan. Hal mana peningkatan ilmu oleh pemberi layanan sangat penting. Ditambah lagi dengan penerapan teknologi baru dalam mengatasi masalah maslah penyakit.

Hal tersebut akan membantu terwujudnya mutu pelayanan yang optimal dimana pelayanan optimal tersebut akan meningkatkan keberhasilan suatu perusahaan.

Tabel 4.14.

Hubungan Kehandalan dengan Kepuasaan Ibu pada pelayanan KIA. 


\begin{tabular}{|c|c|c|c|c|c|}
\hline \multirow{3}{*}{$\begin{array}{l}\text { Kehandala } \\
\mathrm{n}\end{array}$} & \multicolumn{3}{|c|}{ Kepuasan } & \multirow{2}{*}{\multicolumn{2}{|c|}{ Total }} \\
\hline & \multicolumn{2}{|c|}{ Tidak Puas } & \multirow[t]{2}{*}{ Puas } & & \\
\hline & $\%$ & & & $\%$ & $\mathrm{n}$ \\
\hline Tidak Baik & 21 & 91,3 & 2 & 8,7 & 23 \\
\hline Baik & 13 & 16,9 & 64 & 83,1 & 77 \\
\hline Jumlah & 34 & 34 & 66 & 66 & 100 \\
\hline
\end{tabular}

Analisa hasil penelitian aspek kehandalan dengan menunjukkan bahwa kehandalan yang baik memberikan prosentase persepsi kepuasaan yang lebih banyak yaitu $83,1 \%$ dibandingkan dengan kehandalan yang tidak baik yaitu $8,7 \%$. Dari kehandalan yang baik perlu untuk dipertahankan. Kehandalan yang meliputi indikator kemampuan dari pemberi layanan akan menjanjikan penerima layanan untuk merasa puas.

Kehandalan yang tidak baik akan mempunyai aspek tidak puas yang lebih banyak yaitu 91,3\% dibandingkan dengan kehandalan yang baik yaitu $16,9 \%$. Kehandalan yang tidak baik perlu solusi untuk peningkatan kemampuan dari pemberi layanan. Peningkatan kehandalan dapat dilakukan secara bertahap untuk kempuan dalam hal peningkatan ketrampilan teknologi terkini.

Dari hasil penelitian hubungan aspek kehandalan dengan kepuasaan ibu, menunjukkan bahwa kehandalan yang baik akan mendapatkan responden dengan prosentase puas yang lebuh banyak dibandingkan dengan aspek kehandalan yang tidak baik. Hal ini membuktikan bahwa kehandalan memang salah satu faktor untuk mewujudkan kepuasaan pelanggan. Aspek kehandalan adalah cara ukur untuk membuktikan atau mengatahui sejauh mana pelanggan yang dilayani bisa merasa puas atau tidak.

Hasil uji Correction Continuity dengan tingkat kesalahan $(\alpha) 5 \%$, didapatkan hasil nilai signifikan atau probabilitas 0.001 maka Ho ditolak dan Ha diterima,sehingga dapat disimpulkan bahwa ada hubungan antara Kehandalan dengan Kepuasaan Ibu pada pelayanan KIA.

Hasil uji diatas menunjukkan bahwa memang terdapat hubungan yang signifikan antara kehandalan dengan kepuasaan pasien. Dengan hehandalan yang baik akan terwujud kepuasaan pasien. Oleh sebab itu penelitian memang suatu wahana yang tepat untuk mengapresiasikan ilmu dan menambah wacana. Merapkan ilmu dalam kehidupan sehari dan menambah wahana ke ilmuan.

Hasil penelitian dari aspek daya tanggap, responden yang mempersepsikan daya tanggap tidak baik sebanyak $38 \%$ responden. Menurut Nurmawati, 2013. Dimensi Responsiviness (Respon/ketanggapan), terdiri atas indikator : merespon setiap pelanggan/pemohon yang ingin mendapatkan pelayanan, petugas/aparatur melakukan pelayanan dengan cepat, petugas/aparatur melakukan pelayanan dengan tepat, petugas/aparatur melakukan pelayanan dengan cermat, petugas/aparatur melakukan pelayanan dengan waktu yang tepat, semua keluhan pelanggan direspon oleh petugas.

Dari hasil analisa jawaban didapatkan indikator yang meyebabkan responden mempersepsikan tidak baik yaitu bahwa mereka harus menunggu lebih dari 10 menit untuk mendapatkan pelayanan yaitu sebanyak 21\%. Dan masih ada responden yang mempersepsikan bahwa bidan menerima keluhan dengan tidak baik yaitu $23 \%$. Dalam hal ini perlu perhatian dan peningkatan etos kerja. Pemberi 
layanan harus menjadi pendengar yang baik.

Dengan respon yang kurang baik akan memberikan kesan tidak baik pada penerima layanan. Padahal pemberi layanan harus mengutamakan keperluan pelanggan. Dengan respon yang baik akan menjalin hubungan yang baik anatar pemberi layanan dengan penerima. Sehingga kepuasaan pasien yang didapatkan akan disebarkan melalui komunikasi dari mulut ke mulut.

Menurut Purwoastuti, dkk 2015 menyebutkan bahwa kelangsungan pemanfaatan jasa oleh pengguna jasa pada suatu layanan ditentukan oleh kebutuhan pribadi pengguna jasa dan pengalaman masa lalu yang didapat oleh penguna jasa. Jadi pengalaman yang kurang baik akan memberikan kesan yang tidak baik. Sehingga pelanggan enggan untuk melakukan kunjungan ulang pada layanan yang mengecewakan. Karena layanan tersebut tidak sesuai harapan untuk bisa memenuhi kebutuhan pribadinya.

Tabel 4.15.

Hubungan Daya Tanggap dengan Kepuasaan Ibu pada pelayanan KIA.

\begin{tabular}{|c|c|c|c|c|c|c|}
\hline \multirow{3}{*}{$\begin{array}{l}\text { Daya } \\
\text { Tanggap }\end{array}$} & \multicolumn{4}{|c|}{ Kepuasan } & \multirow{2}{*}{\multicolumn{2}{|c|}{ Total }} \\
\hline & \multicolumn{2}{|c|}{ Tidak Puas } & \multicolumn{2}{|c|}{ Puas } & & \\
\hline & $\mathrm{n}$ & $\%$ & $\mathrm{n}$ & $\%$ & $\mathrm{n}$ & $\%$ \\
\hline Tidak & 27 & 71,1 & 11 & 28,9 & 38 & 100 \\
\hline Baik & & & & & & \\
\hline Baik & 7 & 11,3 & 55 & 88,7 & 62 & 100 \\
\hline Jumlah & 34 & 34 & 66 & 66 & $\begin{array}{l}10 \\
0\end{array}$ & 100 \\
\hline
\end{tabular}

Analisa hasil penelitian hubungan aspek daya tanggap dengan kepuasan menunjukkan bahwa daya tanggap yang baik mempunyai prosentase puas yang lebih banyak yaitu $88,7 \%$ dibandingkan dengan daya tanggap yang tidak baik yaitu 28,9\%. Daya tanggap yang baik akan memberikan respon yang cepat terhadap kebutuhan penerima layanan. Layanan yang diberikan akan serasa lebih cepat dan memenuhi kebutuhan pelanggan.

Dari data di atas menunjukkan bahwa dengan daya tanggap yang baik akan memperoleh prosentase kepuasaan yang lebih banyak daripada daya tanggap yang tidak baik. Hal tersebut membuktikan bahwa daya tanggap sangat berpengaruh terhadap kepuasaan pasein. Dimana daya tanggap merupakan dimensi yang mendukung terwujudnya kepuasaan pelanggan.

Daya tanggap merupakan faktor yang melekat erat dalam karakteristik pemberi layanan. Hal tersebut sesuai dengan pendapat dari Purwoastuti, dkk, 2015. Bahwa layanan kesehatan dikatakan bermutu bila mampu memenuhi kebutuhan yang dirasakan oleh pelanggan. Pelayanan tersebut diberikan secara sopan, santun, tepat waktu, tanggap serta mampu menyembuhan keluhan dari pelanggan.

Hasil uji Correction Continuity dengan tingkat kesalahan $(\alpha) 5 \%$, didapatkan hasil nilai signifikan atau probabilitas 0.001 maka Ho ditolak dan Ha diterima, sehingga dapat disimpulkan bahwa ada hubungan Daya Tanggap dengan Kepuasaan Ibu pada pelayanan KIA.

Menurut Moenir, 2002 dalam buku Purwoastuti dkk, 2015, faktor penentu mutu layanan adalah adanya aturan yang menjadi landasan kerja layanan. Dengan landasan aturan yang ditetapkan sebagai SOP akan memberikan banyak manfaat. Dimana penerima layanan merasa tidak di 
bohongi mengenai waktu, biaya dan jenis layanan yang diterimanya.

Tabel 4.16.

Hubungan Jaminan dengan Kepuasaan Ibu pada pelayanan KIA.

\begin{tabular}{|c|c|c|c|c|c|c|}
\hline \multirow{3}{*}{$\begin{array}{l}\text { Jamin } \\
\text { an }\end{array}$} & \multicolumn{4}{|c|}{ Kepuasan } & \multirow{2}{*}{\multicolumn{2}{|c|}{ Total }} \\
\hline & \multicolumn{2}{|c|}{ Tidak Puas } & \multicolumn{2}{|c|}{ Puas } & & \\
\hline & $\mathrm{n}$ & $\%$ & $\mathrm{n}$ & $\%$ & $\mathrm{n}$ & $\%$ \\
\hline Tidak & 19 & 52,8 & 17 & 47,2 & 36 & 100 \\
\hline Baik & & & & & & \\
\hline Baik & 15 & 23,4 & 49 & 76,6 & 64 & 100 \\
\hline $\begin{array}{l}\text { Jumla } \\
\mathrm{h}\end{array}$ & 34 & 34 & 66 & 66 & 100 & 100 \\
\hline
\end{tabular}

Nilai $\mathrm{x}^{2}$ hitung $=7,580 \quad$ Sig $=0,006$

Analisa dari hasil penelitian hubungan jaminan dengan kepuasaan ibu menunjukkan bahwa pada responden dengan aspek jaminan yang baik akan mempuyai prosentase puas yang lebih banyak yaitu $76,6 \%$ dibandingkan dengan jaminan yang tidak baik yaitu 47,2\%. Dari hasil penilitian mengenai aspek jaminan menunjukkan hasil bahwa dengan jaminan yang baik akan memberikan prosentasi kepuasaan yang lebih banyak dibandingkan dengan jaminan yang tidak baik. Hal tersebut sudah sesuai dengan teori yang mengungkapkan bahwa aspek untuk mewujudkan kepuasaan pasien adalah jaminan yang baik.

Responde dengan aspek jaminan yang tidak baik cenderung untuk memiliki aspek tidak puas yang lebih banyak yaitu 52,8\% dibandingkan dengan jaminan yang baik akan mempuyai posebtase tidak puas yaitu $23,4 \%$.

Hasil uji Correction Continuity dengan tingkat kesalahan $(\alpha) 5 \%$, didapatkan hasil nilai signifikan atau probabilitas 0.006 maka Ho ditolak dan Ha diterima, sehingga dapat disim- pulkan bahwa ada hubungan antara Jaminan dengan Kepuasaan Ibu pada pelayanan KIA.

Dari hasil uji diatas menunjukkan bahwa ada hubungan antara jaminan dengan kepuasaan pelanggan. Hal tersebut membuktikan bahwa teori yang ada memang sudah benar adanya. Sehingga penelitian ini merupakan wahana yang tepat untuk mencari fakta kebenaran.

Hasil penelitian menunjukkan bahwa persepsi empati tidak baik sebanyak 34\% responden. Menurut Hardiyansyah, 2011. Dimensi Empathy (Empati), terdiri atas indikator : mendahulukan kepentingan pemohon / pelanggan, petugas melayani dengan sikap ramah, petugas melayani dengan sikap sopan santun, petugas melayani dengan tidak diskriminatif (membedabedakan), petugas melayani dan menghargai setiap pelanggan.

Analisis jawaban dari responden masih ada $14 \%$ responden yang mempersepsikan bahwa bidan tidak segera memeriksa pasien padahal sudah waktunya pemeriksaan. Serta $14 \%$ bidan tidak memberi salam pada pasien. Dari analisa tersebut menunjukkan bahwa aspek empati yang terdiri dari beberapa indikator sudah hampir terpenuhi. Hanya beberapa prosentase yang masih tidak baik. Yaitu dari segi indikator keutamaan kepentingan dan keramahan pelayan.

Keramahan yang diberikan oleh pemberi layanan mungkin dipersepsikan lain oleh penerima layanan. Karena karakter yang berbeda pada pemberi layanan. Dengan moto $3 \mathrm{~S}$ yang sudah terpapang di tempat layanan sudah memberikan motivasi tersendiri pada pemebri layanan. Mereka akan selalu teringat untuk bisa 
memberikan salam, sapa dan senyum pada semua penerima layanan.

Tabel 4.17.

Hubungan Empati dengan Kepuasaan Ibu pada pelayanan KIA.

\begin{tabular}{lllllll}
\hline \multirow{2}{*}{$\begin{array}{l}\text { Empat } \\
\mathrm{i}\end{array}$} & \multicolumn{2}{l}{ Kepuasan } & \multicolumn{2}{c}{ Total } \\
\cline { 2 - 6 } & \multicolumn{2}{c}{ Tidak Puas } & \multicolumn{2}{c}{ Puas } & \multicolumn{2}{c}{} \\
\cline { 2 - 6 } & $\mathrm{n}$ & $\%$ & $\mathrm{n}$ & $\%$ & $\mathrm{n}$ & $\%$ \\
\hline Tidak & 20 & 58,8 & 14 & 41,2 & 34 & 100 \\
Baik & & & & & & \\
Baik & 14 & 21,2 & 52 & 78,8 & 66 & 100 \\
\hline $\begin{array}{l}\text { Jumla } \\
\mathrm{h}\end{array}$ & 34 & 34 & 66 & 66 & $\begin{array}{l}10 \\
0\end{array}$ & 100 \\
\hline
\end{tabular}

Nilai $\mathrm{x}^{2}$ hitung $=12,520 \quad$ Sig $=0,001$

Analisa hasil penelitian menunjukkan bahwa pada responden dengan aspek empati yang baik akan mempunyai prosentase puas yang lebih banyak yaitu $78,8 \%$ dibandingkan dengan empat yang tidak baik yaitu mempunyai prosentase puas yang lebih sedikit $41,2 \%$. Dari hasil penelitian diatas menunjukkan hasil bahwa empati yang baik akan memperoleh prosentase rasa puas lebih banyak dibandingkan dengan empati yang tidak baik. Oleh karena itu pemberi pelayanan dari segi jasa terutama dalam bidang kesehatan sangat penting. Dengan rasa empati yang baik akan menciptakan rasa puas dari pelanggan.

Aspek empati yang tidak baik akan mempunyai prosentase tidak puas lebih banyak yaitu 58,8\% dibandingkan dengan empati yang baik yaitu $21,2 \%$.

Hasil uji Correction Continuity dengan tingkat kesalahan $(\alpha) 5 \%$, didapatkan hasil nilai signifikan atau probabilitas 0.001 maka Ho ditolak dan $\mathrm{Ha}$ diterima, sehingga dapat disimpulkan bahwa ada hubungan antara Empati dengan Kepuasaan Ibu pada pelayanan KIA.

Dari hasil uji diatas menunjukkan adanya hubungan antara empati dengan kepuasaan pasien. Hal tersebut membuktikan bahwa aspek empati merupakan aspek penentu keberhasilan mutu layanan. Sehingga penelitian ini sangatlah bermanfaat untuk membuktikan kebenaran dari teori yang ada.

\section{SIMPULAN}

Hasil analisa penelitian menunjukkan bahwa pada responden dengan persepsi bukti fisik, kehandalan, daya tanggap, jaminan dan empati yang baik akan memperoleh prosentase rasa puas lebih banyak di bandingkan yang responden dengan bukti fisik, kehandalan, daya tanggap, jaminan dan empati yang tidak baik. Uji chi squre terhadap 5 dimensi mutu didapatkan hasil bahwa ke 5 dimensi mutu tersebut ada hubungan dengan kepuasaan pasien yaitu hasil $p$ value $<0,05$.

\section{SARAN.}

Penelitian ini diharapkan bisa memberikan masukan bagi pelaksana poli KIA dan PONED selaku pemberi pelayanan KIA untuk lebih bekerja secara profesional dengan memperhatikan prinsip service quality. Ketidakpuasan yang dirasakan oleh pengunjung poli KIA bisa dijadikan motivasi bagi pemberi lanyanan terutama bidan untuk bisa memberi layanan yang lebih baik. Terutama keramahan, senyum, salam dan sapa. Bidan diharapkan mampu memberikan jaminan harga terhadap pasien dengan jelas dan transparan. Diharapkan juga bidan bisa meningkatkan kehandalan 
dalam memberikan pelayanan demi keamanan dirinya sendiri dan pasien. Mencegah hal-hal yang menyebabkan kerugian bagi diri sendiri, pasien dan keluarganya.

\section{KEPUSTAKAAN.}

Badan Litbangkes kemenkes RI, 2013. Riset Kesehatan Dasar 2013, Jakarta.

BKKBN Kemenkes RI, 2013. Survei Demografi Dan Kesehatan Indone-sia.

Dinas Kesehatan Kabupaten Blora, 2015. Laporan Kesehatan Keluarga. Blora.

Dinas Kesehatan Provinsi Jawa Tengah, 2014. Profil Jawa Tengah. Semarang.

Hardiyansyah, 2011. Kualitas Pelayanan Publik. Gava Media, Yogyakarta.

Harentama Fardhani. 2010. Analisis Faktor Faktor Yang Mempengaruhi Kepuasaan Masyarakat Pada Pelayanan Badan Pelayanan Per-ijinan Terpadu Kota Semarang. Publish: repository UNDIP Sema-rang

Hidayat, A. Aziz Alimul, 2008. Konsep Dasar Keperawatan. Salemba Medika. Jakarta 2008.Jakarta 2013.

Kementerian Kesehatan RI, 2013. Pedoman Penyelenggaraan Puskesmas Mampu Poned, Jakarta 2013.

Kirom B, 2015. Mengukur Kinerja Pelayanan Dan Kepuasan Konsu-men. Reka Cipta. Bandung 2015.
Laila Khairani. 2011. Faktor Faktor Yang Mempengaruhi Kepuasaan Pasien Rawat Jalan RSUD Pasaman Barat. Tesis. Universitas An-dalas Padang.

Nurmawati, 2013. Mutu Pelayanan Kebidanan. Trans Info Media. Jakarta 2013

Purwoastuti Endang, dkk, 2015. Mutu Pelayanan Kesehatan Dan Kebidanan. Pustaka Baru Press. Yogjakarta 2015.

Supranto, J. (2006). Pengukuran Tingkat Kepuasan Pelanggan Untuk Menaikan Pangsa Pasar. Jakarta :PT.Rineka Cipta.

Wike Diah Anjaryani. 2009. Kepuasan Pasien Rawat Inap Terhadap Pela-yanan Perawat Di RSUD Tugurejo Semarang. 